AWEJ for Translation \& Literary Studies, Volume2, Number 1, February 2018 DOI: http://dx.doi.org/10.24093/awejtls/vol2no1.7

Pp. 97-105

\title{
The Representation of Puritans in William Shakespeare's Twelfth Night
}

\author{
Rachid MEHDI \\ Department of English, Faculty of Art \\ Abderahmane-Mira University of Bejaia, Algeria
}

\begin{abstract}
This article is a study on the representation of Puritans in William Shakespeare's Twelfth Night; or, What You Will, one of his most popular comic play in the modern theatre. In mocking Malvolio's morality and ridiculous behaviour, Shakespeare wanted to denounce Puritans' sober society in early modern England. Indeed, Puritans were depicted in the play as being selfish, idiot, hypocrite, and killjoy. In the same way, many other writers of different generations, obviously influenced by Shakespeare, have espoused his views and consequently contributed to promote this anti-Puritan literature, which is still felt today. This article discusses whether Shakespeare's portrayal of Puritans was accurate or not. To do so, the writer first attempts to define the term "Puritan," as the latter is quite equivocal, then take some Puritans' characteristics, namely hypocrisy and killjoy, as provided in the play, and analyze them in the light of the studies of some historians and scholars, experts on the post Reformation Puritanism, to demonstrate that Shakespeare's view on Puritanism is completely caricatural.
\end{abstract}

Keywords: caricature, early modern theatre, Malvolio, Puritans, satire

Cite as: MEHDI, R. (2018). The Representation of Puritans in William Shakespeare's Twelfth Night. Arab World English Journal for Translation \& Literary Studies, 2 (1).

DOI: http://dx.doi.org/10.24093/awejtls/vol2no1.7 